\title{
Myxozoan infection in the muscle layer of the intestine of Rhamdia quelen from the Amazon River Basin, Brazil
}

\author{
Infecção por Myxozoa na camada muscular intestinal do Rhamdia quelen \\ da Bacia do Rio Amazonas, Brasil
}

\begin{abstract}
Jacqueline Pompeu Abrunhosa ${ }^{\mathrm{I}}$ Michele Velasco Oliveira da Silva ${ }^{\mathrm{I}}$ José Ledamir Sindeaux Neto $^{\mathrm{I}}$ Patrícia de Fátima Sacco dos Santos ${ }^{I}$ Patrícia Santos Matos ${ }^{\text {II }}$ Osimar de Carvalho Sanches ${ }^{\text {II }}$ Edilson Rodrigues Matos ${ }^{I^{*}}$
\end{abstract}

ABSTRACT

The present study investigated the morphology and pathology associated with the occurrence of cysts caused by Myxobolus sp. in the intestine of the silver catfish Rhamdia quelen. Comparisons with the other Myxobolus species that infect the intestines of cyprinids and siluriforms revealed that the pyriform spores of Myxobolus sp. are similar in shape to those described previously in M. miyairii, M. duodenalis and $\boldsymbol{M}$. cunhai, but different in size. Morphometric analyses revealed that mature spores of Myxobolus sp. $(10.9 \times 5.1 \mu \mathrm{m})$ are smaller than those of most species except M. cunhai $(10.0 \times 5.0 \mu \mathrm{m})$, which has been described infecting the Brazilian catfish Pimelodus clarias, although the spores differ morphologically in relation to the shape of the polar capsules. Further research is necessary in order to clarify the taxonomic and phylogenetic relationships among these congeneric species.

Key words: Myxobolus, histopathology, fish parasites, catfish, neotropical.

RESUMO

$O$ presente estudo investigou a morfologia e patologia associada com a ocorrência de cistos de Myxobolus sp. no intestino do peixe siluriforme Rhamdia quelen. Comparações com outras espécies de Myxobolus que têm infectado intestinos de carpas e bagres de água doce demonstraram que os esporos piriformes de Myxobolus sp. são similares no formato dos anteriormente descritos para $\mathbf{M}$. miyairii, M. duodenalis e M. cunhai, diferindo, no entanto, quanto ao tamanho. As análises morfométricas revelaram que os esporos maduros de Myxobolus sp. (10,9 x 5,1 $1 \mu \mathrm{m})$ são menores do que os da maioria das espécies, exceto para $\boldsymbol{M}$. cunhai $(10,0 \times 5,0 \mu \mathrm{m})$, que foi descrito infectando o bagre brasileiro Clarias pimelodus, embora os esporos sejam diferentes morfologicamente em relação à forma das cápsulas polares. Futuras pesquisas são necessárias para esclarecer as relações taxonômicas e filogenéticas entre espécies congêneres.

Palavras-chave: Myxobolus sp., histopatologia, parasitas de peixe, bagres, neotropical.

\section{INTRODUCTION}

The Myxozoa Grassé, 1970 are a heterogeneous group with approximately 60 genera (KENT et al., 2001; LOM \& DYKOVÁ, 2006), which are widespread in aquatic environments, both freshwater and marine. Most of these parasites are considered pathogenic, infecting a variety of tissue in different types of organ, such as liver, kidneys, gills, gonads, intestines, and skin (LOM \& DYKOVÁ, 2006).

The known species of Myxobolus BÜTSCHLI, 1882 (Myxobolidae) are important pathogens in freshwater and marine fish (LOM \& DYKOVÁ, 1992; EIRAS et al., 2005). There are few reports of Myxobolus cysts in the intestines of fish; although, a number of histopathological descriptions are available. These include MOLNÁR's (2002) description of M. cyprinicola parasitizing Cyprinus carpio LINNAEUS, 1758 from Lake Balaton in Hungary, M. nodulointestinalis in Barbus spp. from

\footnotetext{
'Laboratório de Pesquisa Carlos Azevedo, Universidade Federal Rural da Amazônia (UFRA), 66077-901, Belém, PA, Brasil. E-mail: edilson.matos9@gmail.com. "Corresponding author.

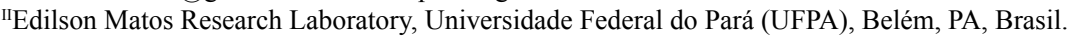

IIICentro de Diagnóstico Veterinário (CDAPVET), Presidente Prudente, SP, Brasil.
} 
Khozestan, Iran (MAGAHMI et al., 2008) and $\boldsymbol{M}$. nodulointestinalis in B. sharpeyi GUNTHER, 1874 from southwest Iran (MASOUMIAN et al., 1996).

The freshwater silver catfish, Rhamdia quelen (QUOY \& GAIMARD, 1824), is a siluriform reported in the Amazon region (FOWLER, 1951). It is a commercially important fishery resource in northern Brazil (BRASIL, 2011), and is also farmed at many sites in the Brazilian states of Rio Grande do Sul and Santa Catarina (GOMES et al., 2000; BALDISSEROTTO \& RADÜNZ NETO, 2004). Despite its importance, few studies have been published on the microparasites found in this species; although, MATOS et al. (2005) have described a new myxozoan species, Henneguya rhamdia, discovered in the gills of $\boldsymbol{R}$. quelen. The present study described the characteristics and histopathological features of the infection by Myxobolus sp. in the intestinal tract of $\boldsymbol{R}$. quelen.

\section{MATERIALS AND METHODS}

From January to December 201450 adults of $\boldsymbol{R}$. quelen were captured in two rivers in the Brazilian state of Pará, the Paracauari River in Salvaterra $\left(00^{\circ} 45 \mathrm{~S} / 48^{\circ} 31 \mathrm{~W}\right)$ and the Arari River at Cachoeira do Arari $\left(01^{\circ} 00 \mathrm{~S} / 48^{\circ} 57 \mathrm{~W}\right)$ on Marajó Island. Fish were transported live in aerated water from the respective habitats to the Carlos Azevedo Research Laboratory at UFRA in Belém (Pará, Brazil). Specimens were maintained in aquaria until necropsy.

After being anesthetized with tricaine methanesulfonate (50mg L-1) (MS222 SIGMA), the fish were euthanized and dissected in accordance with the procedures approved by the UFRA ethics committee for animal experimentation. Necropsy began with an incision in the abdominal cavity. The organs were examined under a stereomicroscope and the cysts were analyzed by light microscopy.

The cysts were found attached to the intestinal tract of the hosts. Small samples of each parasitized intestine were extracted and pressed between a slide and coverslip with a droplet of water for observation using light microscopy (LM). After confirmation of the parasitism, tissue samples from a single fish with a thickness of approximately $5 \mathrm{~mm}$ were collected and fixed in Davidson's solution for $24 \mathrm{~h}$ and then processed and stained using the hematoxylin-eosin, Masson trichrome, and Ziehl Neelsen techniques (LUNA, 1968).

Fresh plasmodia with mature spores were examined morphologically and morphometrically under a light microscope, following KUDO (1921). Thirty spores from each of 10 parasitized fishes were measured (in mm) and mounted on slides with a coverslip and photographed under a Zeiss Primo Star optical microscope equipped with a Zeiss AxioCam ERc 5s photographic camera and the AxioVision 5.1 software.

\section{RESULTS}

Ten out of $50 \boldsymbol{R}$. quelen specimens analyzed in the present study (prevalence: $20 \%$ ) presented parasitic infection by Myxobolus sp. in the final portion of the intestine. The macroscopic observation of these parasitized individuals revealed presence of whitish, ellipsoidal to ovoid cysts averaging $345 \pm 46.9 \mu \mathrm{m}$ (213-408) in length and $195 \pm 26.5 \mu \mathrm{m}(122-245)$ in width, in the inner intestine (Figure 1A). Each parasitized fish had 15 cysts in the intestines.

Light microscopy showed that the cysts were filled with spores, and when ruptured, mature pyriform spores averaging $10.9 \mu \mathrm{m}$ (10.011.6) in length and $5.1 \mu \mathrm{m}(4.2-5.4)$ in width were observed. The spores had two polar capsules (PCs) of equal size $5.3 \pm 0.6 \mu \mathrm{m}$ (5.1-5.6) long and 1.6 $\pm 0.36 \mu \mathrm{m}$ (1.3-1.7) wide (Table 1). Each polar capsule contained a polar filament, although it was not possible to confirm the number of coils of the polar filaments under conventional light and differential interference contrast microscopy (DIC/ OLYMPUS).

Sporoplasm was observed in the final portion of the spore body (Figure 1D). Morphological comparisons with other intestine-dwelling Myxobolus found in cyprinids and freshwater siluriforms are shown in table 1.

Histopathological analysis based on Ziehl Neelsen staining revealed Myxobolus sp. cysts in the muscle layer of intestine (Figure 1B), while the Masson trichrome staining highlighted degeneration and inflammatory infiltration in the lamina propria (Figure 1C). A number of parasitic cysts were observed in the circular and longitudinal layers of the muscle tissue (Figures 1B, 1C) in which the whitish cysts were observed pressing on the luminal mucosa, bulging into the abdominal cavity, and lined by serosal layer.

Cysts were coated with collagen fibers and contained numerous Myxobolus sp. spores. A discreet mixed inflammatory infiltrate surrounded the cysts (Figure 1C). 


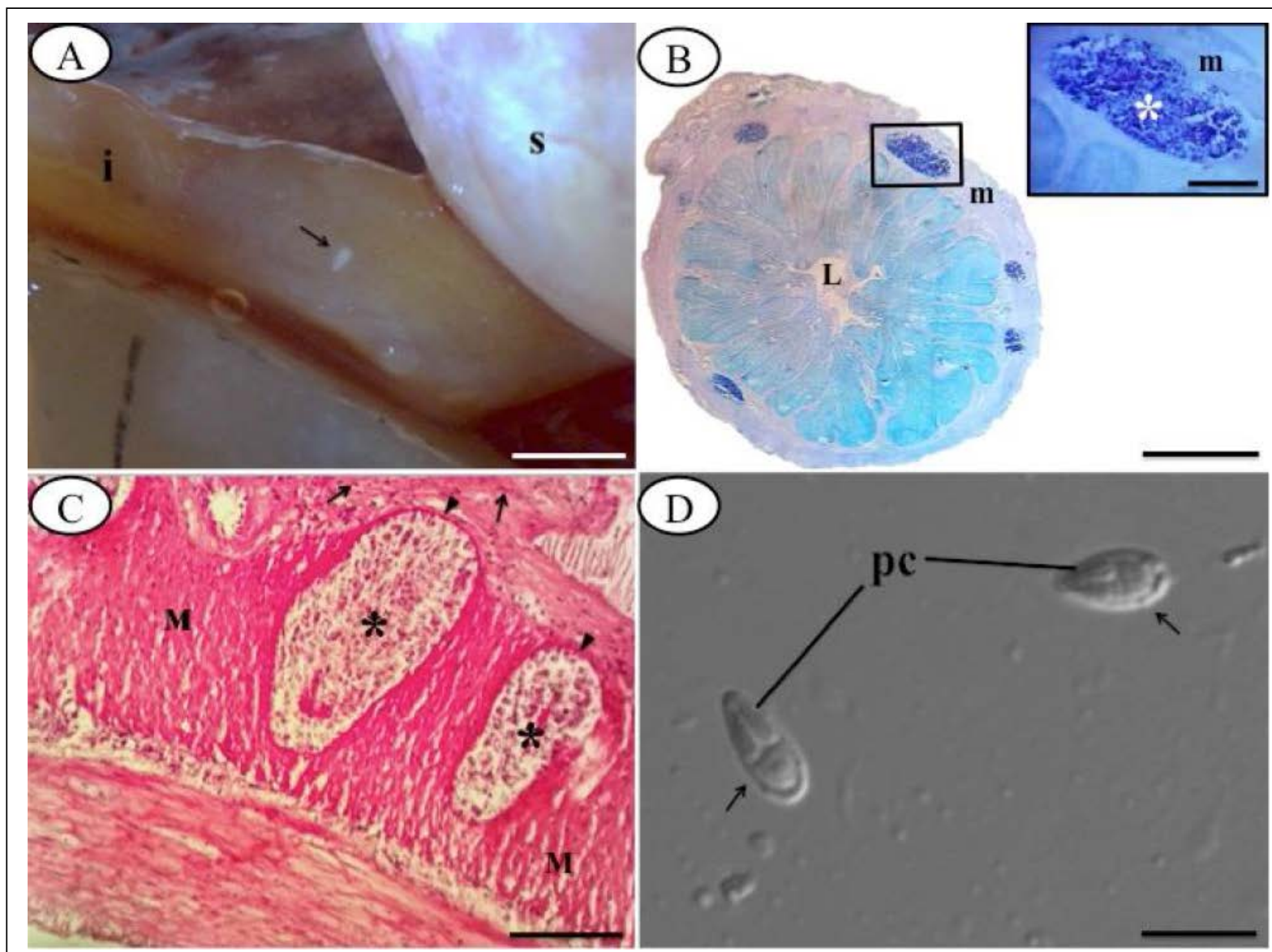

Figure 1 - A- Myxobolus sp. cyst in the Rhamdia quelen intestines (arrow), intestine (i), and stomach (s). Bar, 1.5mm. B - Cross-sectional histological section of the $\boldsymbol{R}$. quelen intestine stained with Ziehl Nielsen marking the Myxobolus sp. cysts in the muscle layer of

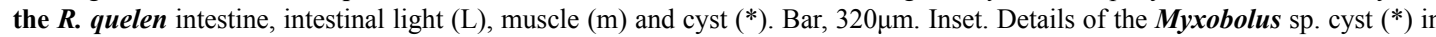
muscle $(\mathrm{m})$. Bar, $70 \mu \mathrm{m}$. C - Transversal section of the intestine with cysts $(*)$ in the muscle layer $(\mathrm{M})$, showing compression on the mucous region (heard of arrow) and inflammatory infiltration in the mucous intestinal layer (arrows). Intestinal muscle layer

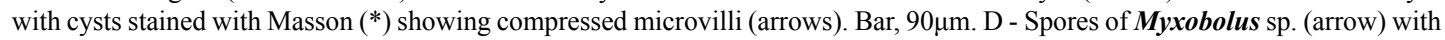
polar capsules (PCs) in Differential interference contrast (DIC). Bar, $10 \mu \mathrm{m}$.

\section{DISCUSSION}

A number of studies have described infections by Myxobolus of the digestive system of freshwater fish, in particular the intestine, of cyprinids (MASOUMIAN et al., 1996; MOLNÁR, 2002; MAGAHMI et al, 2008) and catfish (Siluriformes). In siluriforms, infections have been attributed to Myxobolus bivacuolatus NARASIMHAMURTI \& KALAVATI (1986), Myxobolus cunhai PENIDO (1927), and Myxobolus miyairii KUDO (1919) (Table 1). Structural and morphometric characteristics of these species were compared with those of Myxobolus sp. below.

The myxosporids reported in the muscle layer of the intestine of $\boldsymbol{R}$. quelen had the same characteristics as those defined by LOM \& DYKOVÁ (2006) for the genus Myxobolus. However, morphometric parameters distinguished species of this group, and showed that Myxobolus sp. is closest in size to M. cunhai by PENIDO (1927), but smaller than most other species except $\boldsymbol{M}$. bivacuolatus NARASIMHAMURTI \& KALAVATI (1986) (Table 1).

The spores of Myxobolus sp. were pyriform in shape (Table 1), similar to those of $\boldsymbol{M}$. miyairii, M. duodenalis (KAUR \& SING, 2011) and M. cunhai (PENIDO, 1927), but distinct from the ovoid spores of M. nodulointestinalis (MASOUMIAN et al., 1996) and the spherical ones of M. bivacuolatus (NARASIMHAMURTI \& KALAVATI, 1986). Spores of Myxobolus sp. were 
Table 1 - Comparative measurements of Myxobolus spp. spores $(\mu \mathrm{m})$ infecting catfish Rhamdia quelen intestine with other reported in cyprinid and catfish freshwater species.

\begin{tabular}{|c|c|c|c|c|c|c|c|}
\hline Myxobolus spp. & Spore shape & SL & SW & PCL & PCW & Hosts country/region & References \\
\hline M. nodulointestinalis & Ovoid & 12.6 & 8.1 & 3.6 & 2.4 & Barbus sharpeyi/Iran & MASOUMIAN et al. (1996) \\
\hline M. cyprinicola & Ellipsoidal & 11.8 & 9.0 & 5.0 & 3.2 & Cyprinus carpio/Hungary & MOLNÁR (2002) \\
\hline M. miyairii & Pyriform & 13.3 & 6.6 & 6.5 & 1.9 & Silurus asotus/Japan & LIU et al. (2016) \\
\hline M. gayerae & Elipsoidal & 15.1 & 12.7 & 6.1 & 4.0 & Leucinus cephalus/Hungary & MOLNÁR et al. (2007) \\
\hline M. bivacuolatus & Spherical & 9.0 & - & 4.2 & 3.0 & Clarias batrachus/India & $\begin{array}{l}\text { NARASIMHAMURTI } \\
\text { KAVALATI, (1986) }\end{array}$ \\
\hline M. duodenalis & Pyriform & 9.0 & 3.2 & + & + & Wallago attu/India & KAUR \& SING, (2011) \\
\hline M. cunhai & Pyriform & 10.0 & 5 & + & + & Pimelodus clarias/Brazil & PENIDO (1927) \\
\hline Myxobolus sp. & Pyriform & 10.9 & 5.1 & 5.2 & 1.5 & Rhamdia quelen/Brazil & Present study \\
\hline
\end{tabular}

${ }^{*}$ SL, spore length; SW, spore width, PCL, polar capsule length; PCW, polar capsule width; - without data, + unequal sizes.

similar in size only to those of $\boldsymbol{M}$. cunhai; although, while the spores of Myxobolus sp. have two polar capsules of equal size, in M. cunhai, these structures are extremely elongated and unequal in size.

Parasitism by Myxobolus in the muscle tissue has been described in a number of other fish species. MANRIQUE (2015) described Myxobolus parasitizing skeletal muscle in Piaractus mesopotamicus (HOLMBERG, 1887); although, in contrast with the present study, only myofibril degeneration was observed in this species rather than the inflammatory infiltrates detected in $\boldsymbol{R}$. quelen. However, inflammatory processes associated with Myxobolus sp. cysts have been observed in other species. For example, VELASCO et al. (2012) observed inflammation in the musculature of the palate of Gobioides broussonnetii LACEPÈDE, 1800, which caused a generalized necrosis of the parasitized muscle, consistent with the presence of necrotizing myositis. MATOS et al. (2014) described a discreet inflammatory reaction and multifocal degeneration of the cardiac fibers by Myxobolus sp. in Pimelodus ornatus KNER, 1858 from Marajó Island.

The present study revealed macro and microscope infections by Myxobolus in the muscular layer of the $\boldsymbol{R}$. quelen intestine. This observation contributed to the understanding of the freshwater microparasite fauna, which may contribute to the development of fundamental guidelines for the prevention or control of diseases in fish farming operations. The evidence of microparasitism by Myxobolus in fish may help develop important infection control which will be especially important in the case of $\boldsymbol{R}$. quelen, in both natural and farmed fish, in order to guarantee the health of stocks, and the quality of the end product for human consumption.

\section{BIOETHICS \\ AND \\ BIOSSECURITY COMMITTEE APPROVAL}

The present study was approved by the Ethics Committee for Animal Experimentation of the Universidade Federal Rural da Amazônia (UFRA) (CEUA approval no. 013/2014).

\section{ACKNOWLEDGEMENTS}

We are grateful to Coordenação de Aperfeiçoamento de Pessoal de Nível Superior (CAPES), Conselho Nacional de Desenvolvimento Científico e Tecnológico (CNPq), Fundação Amazônia de Amparo a Estudos e Pesquisas do Pará (FAPESPA), Instituto Brasileiro do Meio Ambiente e dos Recursos Naturais Renováveis (SISBIO/ICMBIO-IBAMA), License no. 27119, and The Edilson Matos Research Laboratory (LPEM-UFPA).

\section{REFERENCES}

BALDISSEROTTO, B.; RADÜNZ NETO, J. Criação do jundiá. Santa Maria: UFSM, 2004. 232p.

BRASIL. Ministério da Pesca e Aquicultura 2011. Produção Pesqueira e Aquícola: Estatística 2011. Available from: <http:// www.mpa.gov.br/files/docs/Boletim_MPA_2011_pub.pdf $>$. Accessed: Nov. 15, 2015.

EIRAS, J.C. et al. Synopsis of the species of Myxobolus Bütschli, 1882 (Myxozoa: Myxosporea: Myxobolidae). Systematic Parasitology, v.61, p.1-46, 2005. Available from: <http://dx.doi. org/10.1007/s11230-004-6343-9>. Accessed: Nov. 15, 2015. doi: $10.1007 / \mathrm{s} 11230-004-6343-9$.

FOWLER, H.W. Os peixes de água doce do Brasil. In: FOWLER, H.W. Arquivos de Zoologia do Estado de São Paulo. São Paulo: São Paulo, 1951. v.6, p.405-625.

GOMES, L.C. et al. Biologia do jundiá Rhamdia quelen (Teleostei, Pimelodidae). Ciência Rural, v.30, n.1, p.179185, 2000. Available from: <http://dx.doi.org/10.1590/S010384782000000100029>. Accessed: Dec. 23, 2015. doi: 10.1590/ S0103-84782000000100029. 
KAUR, H.; SING, R. Two new species of Myxobolus (Myxozoa: Myxosporea: Bivalvulida) infecting Indian freshwater fishes in Punjab Wetlands (India). Parasitology Research, v.108, n.5, p.1075-1082, 2011. Available from: <http://link.springer.com/ article/10.1007\%2Fs00436-011-2307-6M>. Accessed: Apr. 15, 2016. doi: 10.1007/s00436-011-2307-6.

KENT, M.L. et al. Recent advances in our knowledge of the Myxozoa. Journal Eukariotic Microbiology, v.48, n. 4, p. 395-413, 2001. Available from: <http://onlinelibrary.wiley.com/ doi/10.1111/j.1550./pdf $>$. Accessed: Dec. 15, 2015. doi: 10.1111/ j.1550-7408.2001.tb00173.x.

KUDO, R. On the effect of some fixatives upon myxosporidian spores. Transactions of the American Microscopical Society, v.40, p.161-167, 1921.

LIU X.H. et al. Supplemental description and molecular characterization of Myxobolus miyarii Kudo, 1919 (Myxosporea: Myxobolidae) infecting intestine of Amur catfish (Silurus asotus). Parasitology Research, v.115, p.1547-1556, 2016. Available from: <http://link.springer.com/ article/10.1007\%2Fs00436-015-4889-x>. Accessed: Apr. 05, 2016. doi: 10.1007/s00436-015-4889-x.

LOM, J.; DYKOVÁ, I. Myxozoa genera: definition and notes on taxonomy, life-cycle terminology and pathogenic species. Folia Parasitologica, v.53, p.1-36, 2006.

LOM, J.; DYKOVA, I. Protozoan parasites of fishes. AmsterdamLondon-New York-Tokyo: Elsevier, 1992. p.159-235.

LUNA, L.G. Manual of histologic staining methods of the Armed Forces Institute of Pathology. 3.ed. New York: McGrawHill, 1968. 258p.

MAGAHMI, S.S.G. et al. Myxobolus nodulointestinalis intestinal parasite of Barbus fishes in Khozestan, Iran. Journal of Animal Veterynary, v. 7, p.231-234, 2008.

MANRIQUE, W.G. et al. First report of Myxobolus sp. infection in the skeletal muscle of Neotropical freshwater fish Piaractus mesopotamicus. Parasitology Research, v.114, p.20412044, 2015. Available from: <http://10.1007/s00436-015-4454-7.x> Accessed: Mar. 15, 2015. doi: 10.1007/s00436-015-4454-7.
MASOUMIAN, M. et al. Myxobolus nodulointestinalis sp. n. (Myxosporea, Myxobolidae) a parasite of the intestine of Barbus sharpeyi. Diseases of Aquatic Organisms, v.24, p.35-39, 1996.

MATOS, E. et al. Ultrastructural studies of Henneguya rhamdia n. sp. (Myxozoa) a parasite from the Amazon teleost fish, Rhamdia quelen (Pimelodidae). Journal of Eukariotic Microbiology, v.52, n.6, p.532-537, 2005. Available from: <http://10.1111 /j.1550-7408.2005.00063.x>. Accessed: Dec. 15, 2015. doi: 10.1111/j.1550-7408.2005.00063.x.

MATOS, E. etal. Infection of the heart of Pimelodus ornatus(Teleostei, Pimelodidae), by Myxobolus sp. (Myxozoa, Myxobolidae). Brazilian Journal of Veterinary Parasitology, v.23, n.4, p.543-546, 2014. Available from: <http://dx.doi.org/10.1590/S1984-29612014083>. Accessed: Dec. 10, 2015. doi: 10.1590/S1984-29612014083.

MOLNÁR, K. Redescription and histopathology of Myxobolus cyprinicola Reuss, 1906, an intestinal parasite of the common carp (Cyprinus carpio L.). Acta Protozoologica, v.4, p.279-283, 2002. Available from: <http://www1.nencki.gov.pl/pdf/ap/ap628.pdf>. Acessed: Dec. 10, 2015.

MOLNÁR, K. et al. Description of Myxobolus gayerae sp. n. and re-description of $\boldsymbol{M}$. leuciscini infecting European chub from the Hungarian stretch of the river Danube. Diseases of Aquatic Organisms, v.78, p.147-153, 2007. Available from: <http://www. int-res.com/articles/dao2007/78/d078p147.pdf $>$. Accessed: Apr. 15, 2016. doi: 10.3354/dao01854.

NARASIMHAMURTI, C.C.; KALAVATI, C. Two new species of Myxobolus (Myxozoa: Myxosporea: Bivalvulida) infecting an Indian major carp and a catfish in wetlands of Punjab, India. Journal of Parasitic Diseases, v.131, p.153-157, 1986.

PENIDO, J.C.N. Quelques nouvelles Myxosporidies parasites de poissons d'eau douce du Brésil. Comptes Rendus Hebdomadaires Societé de Biologie, v.97, p.850-852, 1927.

VELASCO, M. et al. Necrotizing myositis associated with parasitism by Myxobolus sp. (Myxozoa) in the palate of the violet goby, Gobioides broussonnetii (Gobiidae), from Marajó Island, Brazil. Aquaculture, v.358-359, p.129-131, 2012. Available from: $<$ http://dx.doi.org/10.1016/j.aquaculture.2012.06.033>. Accessed: Oct. 15, 2015. doi: 10.1016/j.aquaculture.2012.06.033. 